УДК 547.972

\title{
КЕМПФЕРОЛ И ЕГО ГЛИКОЗИДЫ ИЗ ЕQUISETUM SILVATICUM L. ХАНТЫ-МАНСИЙСКОГО АВТОНОМНОГО ОКРУГА
}

\author{
(C) В.М. Боначева", Э.Х. Ботиров \\ Сургутский государственный университет ХМАО-Югры, ул. Ленина, 1, \\ Сургуm, 628412 (Россия), e-mail: bwmbeml@mail.ru
}

Из надземной части Equisetum silvaticum L. (хвощ лесной) семейства Equisetaceae выделены три флавоноида, два из которых обнаружены в хвоще лесном впервые. Полученные соединения на основании химических превращений и результатов изучения данных ИК-, УФ-, ${ }^{1} \mathrm{H}$-ЯМР и масс-спектров идентифицированы с кемпферолом, кемпферол-3O- $\beta$-D-галактопиранозил-7-O- $\alpha$-L-рамнопиранозидом и кемпферол-3-О-рутинозил-7-O-рамнозидом.

Ключевые слова: Equisetum silvaticum (L.) Smeet - хвощ лесной, флавоноиды, кемпферол, гликозиды, агликон, $\beta$-D-глюкопиранозид, $\alpha$-L-рамнопиранозид, рутинозид, $\beta$-D-галактопиранозид, гидролиз.

\section{Введение}

В последние десятилетия особым вниманием ученых пользуются растения, содержащие флавоноиды, вследствие их ценности для медицины и фармакологии как источников лекарственных средств широкого спектра действия. Они обладают антиоксидантными, противовоспалительными, капилляроукрепляющими, желчегонными, противоопухолевыми, иммуномодулирующими и другими лечебными свойствами и, что ценно, препараты, созданные на их основе, являются низкотоксичными $[1,2]$.

Большой интерес представляет с этой точки зрения Equisetum silvaticum L., содержащий некоторые ценные для исследователей вещества, но изучен недостаточно, а на территории Ханты-Мансийского автономного округа изучен впервые.

Equisetum silvaticum L. (хвощ лесной) - многолетнее травянистое растение высотой до 60 см. Распространен в лесной зоне тайги, лесотундры, лесостепи, в горнолесных поясах России, Юго-Восточной Азии, Северной Америки. Хвощ лесной чаще можно встретить на опушках лесов, вблизи водоемов, на влажных затененных местах, на заболоченных и торфяных лугах [3]. Этот вид хвоща ядовит для лошадей и крупного рогатого скота.

С давних времен хвощ лесной использовали в народной медицине как лекарственное растение, которое обладает мочегонными, противовоспалительными, противогрибковыми, диуретическими и другими полезными свойствами [4].

Раньше хвощ лесной использовали для окрашивания шерсти в серо-желтый цвет [5-6].

Хвощ лесной по распространенности, богатым сырьевым ресурсам, а также наличию в нем компонентов фенольной природы является наиболее перспективным для химико-фармакологического изучения. Этот факт говорит об актуальности исследований флавоноидов этих растений.

\section{Экспериментальная часть}

Боначева Виктория Михайловна - аспирант кафедры химии, тел. (3462) 76-28-00, e-mail: bwmbeml@mail.ru Ботиров Эркин Хожиакбарович - заведующий кафедрой химии, доктор химических наук, профессор, тел.: (3462) 76-30-91, e-mail: botirov-nepi@ mail.ru
Для выделения флавоноидов воздушно-сухую измельченную надземную часть хвоща лесного (700 г) пятикратно экстрагировали 85\%-м этиловым спиртом при комнатной температуре. Объединенный

\footnotetext{
* Автор, с которым следует вести переписку.
} 
экстракт сгущали в вакууме, разбавляли водой в соотношении $1: 1$ и затем последовательно обрабатывали на делительной воронке петролейным эфиром, хлороформом, этилацетатом и н-бутанолом. После отгонки растворителей получили 1,8 г хлороформной, 9,5 г этилацетатной и 19,5 г бутанольной фракций. Хроматографированием этилацетатной фракции на колонке $(120 \times 3$ см $)$ с силикагелем $(220$ г) в градиентной системе этилацетат-этанол выделили соединение 1. Вещество 1 (выход 0,2 г) элюировано смесью растворителей этилацетат - этанол в соотношении $98: 2$.

Хроматографированием части бутанольной фракции (12 г) на колонке с силикагелем (240 г) в системе растворителей этилацетат - этанол в соотношении (94:6) получили вещество $2(0,45$ г), а вещество 3 (выход 0,8 г) элюировано системой растворителей этилацетат - этанол (86 : 14).

Полученные вещества очищены колоночной хроматографией на полиамиде марки Woelm (Германия) в градиентной системе растворителей хлороформ - этанол.

Для установления месторасположения углеводных остатков проводили щелочной и кислотный (мягкий ступенчатый и полный) гидролиз соединений 2 и 3.

Щелочной гидролиз проводили следующим образом: навеску гликозида растворяли в 0,5\%-м водном растворе гидроксида калия и гидролизовали на кипящей водяной бане с обратным холодильником в течение 2 ч. Раствор нейтрализовали 2\%-м водным раствором серной кислоты, упаривали досуха, продукты идентифицировали методом ТСХ сравнением с подлинными образцами [7-8]. Для осуществления ступенчатого мягкого кислотного гидролиза гликозид нагревали при температуре 50-60 ${ }^{\circ} \mathrm{C}$ в 0,16\%-м водном растворе хлороводородной кислоты. Через каждые 15 мин отбирали пробы и анализировали продукты методом ТСХ, используя стандартные образцы [9].

Полный кислотный гидролиз флавоноидных гликозидов проводили нагреванием на кипящей водяной бане с обратным холодильником раствора 10 мг вещества в 10 мл смеси 5\% соляной кислоты и этанола в соотношении $1: 1$ в течение 2 ч [10]. Осадок агликона, выпавший при отгонке этанола в вакууме, отделяли фильтрованием. Фильтрат упаривали досуха, остаток растворяли в этаноле и углеводы анализировали методом тонкослойной хроматографии в присутствии подлинных образцов моносахаридов в системе растворителей $н$-бутанол - уксусная кислота - вода $(6: 1,5: 2,5)$. Пластинки проявляли смесью $H$-бутанол вода - уксусная кислота - фосфорная кислота - анилин - дифениламин, мл $(60-25-15$ - 10 - 1 - 2 г), высушивали в термостате при $120^{\circ} \mathrm{C}$ в течение 5 мин [11].

УФ-спектры регистрировали на спектрофотометре Specord M 400 в этаноле, ИК-спектры снимали на ИК-Фурье-спектрометре IR Prestige-21. Масс-спектры снимали на хромато-масс-спектрометре Тhermo Finnigan MAT 95 ХР, энергия ионизации 70 эВ. Спектры ${ }^{1}$ Н-ЯМР снимали в ДМСО-d 6 на приборе Вruker Avance III с рабочей частотой 500 МГц. Химические сдвиги приведены в миллионных долях (м.д.) в $\delta$-шкале.

Температуры плавления определяли на столике Кофлера.

Для ТСХ использовали пластинки Sorbfil ПТСХ-П-А-УФ. Пятна флавоноидов обнаруживали обработкой пластинок $1 \%$-м спиртовым раствором $\mathrm{AlCl}_{3}$. Колоночную хроматографию проводили на силикагеле марки КСК 100/160 мкм.

\section{Обсуждение результатов}

Выделенные индивидуальные соединения относятся к классу флавоноидов. Идентификацию полученных веществ проводили на основании результатов химических превращений и спектральных данных. Полученные результаты сравнивали с литературными данными.

3,5,7,4'-тетрагидроксофлавон (кемпферол) (1) - светло-желтое кристаллическое вещество состава $\mathrm{C}_{15} \mathrm{H}_{10} \mathrm{O}_{6}$, т. пл. 268-270 ${ }^{\circ} \mathrm{C}$, масс-спектр (m/z): $\mathrm{M}^{+} 286$. УФ-спектр: $\lambda_{\text {мах }}$ (этанол) 266,369 нм, что характерно для флавонолов; + $\mathrm{NaOH}$ : 281, 415 нм; + $\mathrm{CH}_{3} \mathrm{COOH} 274,387$ нм, поэтому гидроксильная группа в положении 7 - свободна, так как наблюдаем батохромный сдвиг полосы II на 8 нм и полосы I на 18 нм.

В ИК-спектре вещества 1 присутствуют полосы поглощения гидроксильных групп (3323-3277 $\left.\mathrm{cm}^{-1}\right)$, карбонила $\gamma$-пирона $\left(1662 \mathrm{~cm}^{-1}\right)$, ароматических $\mathrm{C}=\mathrm{C}$-связей $\left(1591 \mathrm{~cm}^{-1}\right)$.

В спектре ПМР вещества, снятом в ДМSO-d 6 , проявляются сигналы протонов 3,5,7,4'-тетразамещенного флавонола: 6,19 (Н, д, 2,0 Гц, Н-6), 6,44 (Н, д, 2,0 Гц, Н-8), 6,93 (2Н, д, 8,9 Гц, Н-3', 5'), 8,05 (2Н, д, 8,9 Гц, Н-2',6'), 12,49 (1Н, уш.с, 5-ОН). 
Используя метод ТСХ с подлинным образцом кемпферола в системе растворителей хлороформ этилацетат - этанол в соотношении (6:3:1), а также сравнивая спектральные данные, физико-химические свойства, соединение 1 идентифицировали с 3,5,7,4'-тетрагидроксофлавоном (кемпферолом) [12, 13]. Кемпферол из Equisetum silvaticum L. выделен впервые.

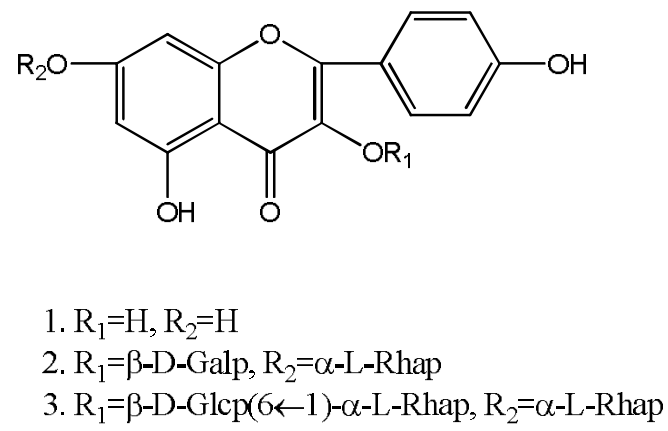

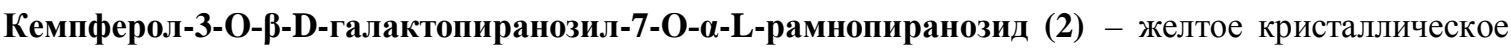
соединение состава $\mathrm{C}_{27} \mathrm{H}_{30} \mathrm{O}_{15}$, т.пл. $188-190{ }^{\circ} \mathrm{C}$, масс-спектр (m/z): $286\left(\mathrm{M}^{+}\right.$агликона кемпферола). УФспектр: $\lambda_{\text {мах }}$ (этанол): 272, 359 нм. + NaOH: 277, 399 нм с уменьшением интенсивности полосы I; $+\mathrm{AlCl}_{3}$ : 276, 348, 400 нм; + $\mathrm{CH}_{3} \mathrm{COOH}$ 267, 354 нм. Анализируя УФ-спектры, можно сделать вывод, что данное вещество относится к 3,7-ди-О-замещенным флавонолам.

В ИК-спектре соединения 2 наблюдаются полосы колебаний гидроксильных групп (3392-3219 см-1), карбонила $\gamma$-пирона (1647 см с $^{-1}$, гликозидных С-О связей (1006-1141 см ${ }^{-1}$ ) и ароматических связей.

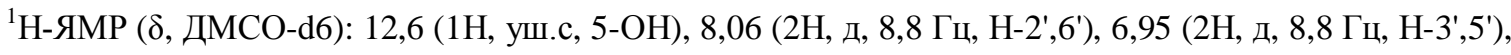
6,80 (1H, д, 1,9 Гц, H-8), 6,43 (1H, 1,9 Гц, H-6), 5,53 (с, H-1" аномер H-Rha), 5,47 ( д, 7,3 Гц, H-1'" аномер HGal), 3,05-3,62 (м, протоны сахарной части), 1,05 (д, 6 Гц, $\mathrm{CH}_{3}-\mathrm{Rha}$ ).

Был проведен полный кислотный гидролиз 14 мг вещества 2 смесью $5 \% \mathrm{HCl}-\mathrm{C}_{2} \mathrm{H}_{5} \mathrm{OH}$ в соотношении 1 : 1 на водяной бане в течение 2 ч. Осадок агликона, выпавший при отгонке этанола в вакууме, отделяли фильтрованием, перекристаллизовали. Получили кемпферол состава $\mathrm{C}_{15} \mathrm{H}_{10} \mathrm{O}_{6}\left(\lambda_{\text {мах }} 266,369\right.$ нм, т. пл. 270-272 $\left.{ }^{\circ} \mathrm{C}\right)$. Фильтрат упаривали досуха, остаток растворяли в этаноле и методом ТСХ в присутствии подлинных образцов обнаружили D-галактозу и L-рамнозу [TCX в системе $\mu$-бутанол - уксусная кислота вода $(6: 1,5: 2,5)]$.

Также провели щелочной гидролиз 10 мг вещества 0,5\%-м водным раствором гидроксида калия (10 мл) на водяной бане в течение 2 ч. В результате получили кемпферол-3-O-ß-D-галактопиранозид и моносахарид L-рамнозу (TCX). Таким образом, можно сделать вывод, что в положении 7 гидроксильная группа замещена L-рамнозой, а 3-ОН гликозилирована D-галактозой.

Сигнал аномерного протона D-галактозы в спектре ${ }^{1} \mathrm{H}$-ЯMP (ДMSO-d 6 ) проявляется в виде дублета с КССВ 7,3 Гц, что свидетельствует о $\beta$-конфигурации D-галактозы.

На основании проведенных химических превращений, а также сравнивая спектральные данные с ли-

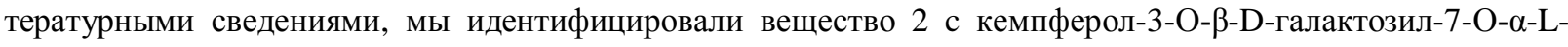

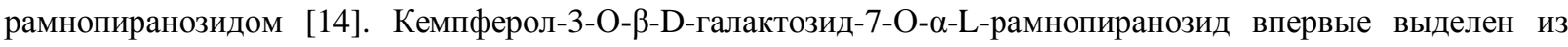
растений рода Equisetum L.

Кемпферол-3-О-рутинозил-7-О-рамнозид (3) - светло-желтое кристаллическое вещество состава

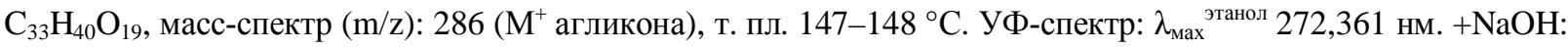
277, $400 \mathrm{HM} ;+\mathrm{AlCl}_{3}: 276,350,402 \mathrm{Hm} ;+\mathrm{CH}_{3} \mathrm{COONa}: 267,356$.

ИК-спектр (см $\left.{ }^{-1}\right): 3373-3277 \mathrm{~cm}^{-1}$ (ОН-группы), $1654 \mathrm{~cm}^{-1}\left(\mathrm{C}=\mathrm{O} \gamma\right.$-пирона), $1591 \mathrm{~cm}^{-1}$ (ароматические $\mathrm{C}=\mathrm{C}$ связи), 1100-1000 см с $^{-1}$ (гликозидные С-О связи) и др.

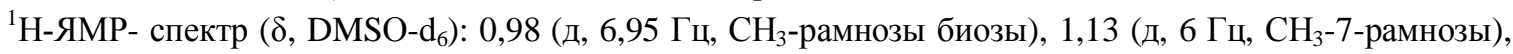
3,05-3,87 (м, протоны углеводной части), 5,16 (д, 2,1 Гц, Н-1"' аномер H-Rha биозы), 5,32 (д, 7,5 Гц, Н-1"' аномер H-Glc), 5,53 (д, 2 Гц, Н-1" аномер H-Rha), 6,42 (H, д, 2,0 Гц, Н-6), 6,76 (Н, д, 2,0 Гц, Н-8), 6,87 (2H, д, 8,8 Гц, Н-3', Н-5'), 8,00 (2Н, д, 8,8 Гц, Н-2', Н-6'), 12,60 (уш.с, 5-ОН).

В результате полного кислотного гидролиза гликозида 3 смесью 5\%-й соляной кислоты и этанола в соотношении 1 : 1 получили кемпферол (4 мг), L-рамнозу и D-глюкозу. 
Для установления месторасположения углеводных остатков нами был проведен щелочной и кислотный мягкий ступенчатый гидролиз данного соединения. В ходе мягкого кислотного гидролиза на первой стадии (через 15 мин) образуются дигликозид, который идентифицировали как кемпферол-3-О-глюкозид7-О-рамнозид, т. пл. $151-153{ }^{\circ} \mathrm{C}$, УФ-спектр: $\lambda_{\text {мах }} 272,359$ нм и моносахарид L-рамноза [4,8]. На второй стадии (через 30 мин) образуется гликозид, т. пл. 177-179 ${ }^{\circ} \mathrm{C}$, УФ-спектр: $\lambda_{\text {мах }} 260,366$ нм и моносахарид Dглюкоза (ТСХ, ИК-спектр). Сравнивая данные с литературой, мы идентифицировали его как кемпферол-7О-рамнозид [15-16].

Также был проведен гидролиз соединения 3 в щелочной среде, методика которого описана выше. При этом было получено вещество с т. пл. $182-185^{\circ} \mathrm{C}$, УФ-спектр: $\lambda_{\text {мах }} 266,352$ нм, которое сравнением с литературными данными идентифицировали как кемпферол-3-О-рутинозид, раннее выделенный из хвоща лесного, и моносахарид L-рамнозу [4]. Углеводный остаток идентифицировали, используя метод TCX, сравнением с подлинным образцом L-рамнозы.

Обобщая полученные данные, а также сравнивая спектральные данные и физико-химические свойства с литературными сведениями, соединение 3 идентифицировали с кемпферол-3-О-рутинозил-7-Орамнозидом [4, 15-17].

\section{Выводы}

Из надземной части хвоща лесного впервые выделены известные флавоноиды: 3,5,7,4'-

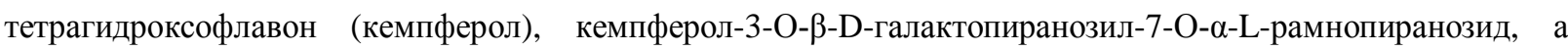
также раннее выделенный кемпферол-3-О-рутинозил-7-О-рамнозид.

Выделенные соединения идентифицированы на основании результатов химических превращений, данных УФ-, ${ }^{1}$ Н-ЯМР, ИК- и масс-спектров.

\section{Список литературы}

1. Hollman P.C.H., Feskens E.I.M., Katan M.B. The Flavonoids in cardio-vascular disease and cancer prevention // Proceed. Soc. Exp. Biol. Med. 1999. Vol. 220, no. 4, Pp. 198-202.

2. Hernandez N.E., Tereschur M.L., Abdala L.R. Antimicrobial activity of flavonoids in medicinal plants from Tafi del Valle (Tucuman, Argentina) // J. Ethnopharmacol. 2000. Vol. 73, №1-2. Pp. 317-322.

3. Flavonoids in Health and Disease, edited by Catherine A Rice-Evans and Lester Packer, New-York, Marsel Dekker, Inc. 2003, 458 p.

4. Коломиец Н.Э., Калинкина Г.И. Сравнительное исследование химического состава видов рода флоры Сибири // Химия растительного сырья. 2010. №1. С. 149-154.

5. Носов А. Лекарственные растения. М., 2001. 348 с.

6. Шамрук С.Г. Лекарственные растения. М., 1989. 286 с.

7. Макаров В.А., Шинкаренко А.Л., Литвиненко В.И., Ковалев И.П. Флавоноидные дигликозиды Prunus spinosa // Химия природных соединений. 1969. №5. С. 366-369.

8. Литвиненко В.И., Макаров В.А. Щелочной гидролиз флавоноидных гликозидов // Химия природных соединений. 1969. №5. С. 366-369.

9. Максютина Н.П., Литвиненко В.И., Ковалев И.П. Неоробинин - новый гликозид из Cheiranthus Allioni // Химия природных соединений. 1966. №6. С. 367-454.

10. Chander R.F.. Harpek K.A. Identification of Saccharides in Anthcyanins and other Flavonoids // Austral. J. Chem. 1961. Vol. 14, N4. Pp. 586-595.

11. Методы исследования углеводов / Пер. с англ. В.А. Несмеянова; под ред. А.Я. Хорлина. М., 1975. 445 с.

12. Markham K.R. Techniques of Flavonoid Identification. London: Academic Press, 1982. 113 p.

13. Yuldashev M.P., Muminova B.A., Drenin A.A., Botirov E.Kh. Flavonoids from the aerial Part of Vicia subvillosa // Chem. Nat. Comp. 2007. Vol. 43. №1. Pp. 34-36.

14. Perez-Jimenez J., Neveu V., Vos F., Scalbert A. Identification of the 100 richest dietary sources of polyphenols: an application of the Phenol-Explorer database // European Journal of Clinical Nutrition. 2010. Vol. 64. Pp. 112-120.

15. Самокина О.В., Шинкаренко А.П. Кемпферол 7-рамнозид из Aconitum orientale // Химия природных соединений. 1969. №5. С. 441.

16. Yonekura-Sakakibara K., Tohge T., Niida R., Saito K. Identification of a Flavonol 7-O-Rhamnosyltransferase Gene Determining Flavonoid Pattern in Arabidopsis by Transcriptome Coexpressi on Analysis and Reverse Genetics // Biological Chemistry. 2007. №2. P. 282.

17. Запесочная Г.Г. Изучение структуры и стереохимии флавоноидных О-рамнозидов с помощью спектроскопии ПМР // Химия природных соединений. 1982. №5. С. 695-709. 
Bonacheva V.M. ${ }^{*}$ Botirov E.Kh. KAEMPFEROL AND ITS GLYCOSIDES FROM EQUISETUM SILVATICUM L. SMEET HUNTS-MANSIJSKOGO OF AUTONOMOUS REGION

Surgut State Universit, Lenina st., 1, Surgut, 628412 (Russia), e-mail: bwmbeml@mail.ru

The article is devoted to the phytochemical study of Glycosides flavonoids Equisetum silvaticum (L.) Smeet . From the overgrown part of Equisetum silvaticum (L.) Smeet of the first flavonoids kaempferol, kaempferol-3-O- $\beta$-D-galactopyranoside7-O- $\alpha$-L-ramnopyranoside and elready kaempferol-3-O-rutinoside-7-O- $\alpha$-L-ramnopyranoside were isolated. The resulting compounds were identified on the basis of results of chemical transformations and IR, UV, 1H-, 13C-NMR and mass spectra.

Keywords: Equisetum silvaticum L. Smeet, flavonoids, kaempferol, glycosides, aglycone, $\beta$-D-glucopyranoside, $\alpha$-Lramnopyranoside, rutinoside, $\beta$-D-galactopyranoside, hydrolysis.

\section{References}

1. Hollman P.C.H., Feskens E.I.M., Katan M.B. Proceed. Soc. Exp. Biol. Med., 1999, vol. 220, no. 4, pp. 198-202.

2. Hernandez N.E., Tereschur M.L., Abdala L.R. J. Ethnopharmacol., 2000, vol. 73, no. 1-2, pp. 317-322.

3. Flavonoids in Health and Disease, edited by Catherine A Rice-Evans and Lester Packer, New-York, Marsel Dekker, Inc. 2003, 458 p.

4. Kolomiets N.E., Kalinkina G.I. Khimiia rastitel'nogo syr'ia, 2010, no. 1, pp. 149-154. (in Russ.).

5. Nosov A. Lekarstvennye rasteniia. [Medicinal plants]. Moscow, 2001, 348 p. (in Russ.).

6. Shamruk S.G. Lekarstvennye rasteniia. [Medicinal plants]. Moscow, 1989, 286 p. (in Russ.).

7. Makarov V.A., Shinkarenko A.L., Litvinenko V.I., Kovalev I.P. Khimiia prirodnykh soedinenii, 1969, no. 5, pp. 366-369. (in Russ.).

8. Litvinenko V.I., Makarov V.A. Khimiia prirodnykh soedinenii, 1969, no. 5, pp. 366-369. (in Russ.).

9. Maksiutina N.P., Litvinenko V.I., Kovalev I.P. Khimiia prirodnykh soedinenii, 1966, no. 6, pp. 367-454. (in Russ.).

10. Chander R.F., Harpek K.A. Austral. J. Chem., 1961, vol. 14, no. 4, pp. 586-595.

11. Metody issledovaniia uglevodov. Ed. A.Ia. Khorlina. [Research methods carbohydrates]. Moscow, 1975. 445 c. (in Russ.).

12. Markham K.R. Techniques of Flavonoid Identification. London: Academic Press, 1982. 113 p.

13. Yuldashev M.P., Muminova B.A., Drenin A.A., Botirov E.Kh. Chem. Nat. Comp., 2007, vol. 43, no. 1, pp. 34-36.

14. Perez-Jimenez J., Neveu V., Vos F., Scalbert A. European Journal of Clinical Nutrition, 2010, vol. 64, pp. 112-120.

15. Samokina O.V., Shinkarenko A.P. Khimiia prirodnykh soedinenii, 1969, no. №5, pp. 441. (in Russ.).

16. Yonekura-Sakakibara K., Tohge T., Niida R., Saito K. Biological Chemistry, 2007, no. 2, pp. 282.

17. Zapesochnaia G.G. Khimiia prirodnykh soedinenii., 1982, no. 5, pp. 695-709. (in Russ.).

\footnotetext{
* Corresponding author.
} 
